\title{
Information Literacy and Cultural Context: Chinese English Language Learners' Understandings of Information Authority
}

\section{Emily Crist and Diana Popa}

\begin{abstract}
Chinese international students are attending higher education institutions in the United States in ever-increasing numbers, and librarians must consider their cultural, sociopolitical, and linguistic backgrounds in information literacy instruction. This exploratory study examines how Chinese international students at a public American university describe, understand, and interpret information literacy concepts, such as authority, through qualitative vignettes and in-depth interviews. The findings of this study further the use of vignettes as a methodological tool in academic librarianship and help librarians resist one-size-fits-all information literacy instruction by addressing and building upon students' cultural understandings and practices of information literacy that they bring into the classroom.
\end{abstract}

\section{Introduction}

In 2017-2018, the number of international students studying within the United States climbed to a record number, reaching 1,094,792, or 5.5 percent of all enrolled students. ${ }^{1}$ The greatest number of these students, accounting for approximately one-third, come from China. ${ }^{2}$ Universities' strategic goals for enrollment reflect this growing trend; for example, in 2013, the University of Vermont's (UVM) strategic plan set goals of international enrollment to rise from 1 percent to 5-7 percent. $^{3}$ Intermediary pathway programs, one enrollment strategy for international students, stress functional integration into the academic community and provide preparatory linguistic, cultural, and academic support prior to full degree-seeking.

While pathway programs provide more holistic educational support within Western academia, universities as a whole must consider the pedagogical implications of the academic and cultural backgrounds of the growing number of international English language learners (ELLs). Similarly, libraries need to consider the implications of this rapid international growth, especially academic instructional librarians who will continue to encounter greater numbers of ELLs in the classroom. Librarians must understand the cultural and linguistic context with which students understand and practice information literacy skills and may be

\footnotetext{
* Emily Crist is Library Director at Champlain College; email: ecrist@champlain.edu. Diana Popa is a Lecturer in the Departments of Education and Linguistics at the University of Vermont; email: dpopa@uvm.edu. A sincere thank-you to the Institute for Research Design in Librarianship for the methodological training, support, and collegiality that helped make this research possible. (2020 Emily Crist and Diana Popa, Attribution-NonCommercial (https://creativecommons.org/licenses/by-nc/4.0/) CC BY-NC.
} 
disadvantaged when unprepared for engaging with students' different cultural understandings and experiences for navigating the information landscape within Western academia.

To inform the teaching of information literacy, librarians turn to professional documents, such as the Association of College \& Research Libraries (ACRL)'s Framework for Information Literacy for Higher Education (Framework), adopted in 2016. ${ }^{4}$ The document, detailing conceptual understandings essential to information literacy, contains knowledge practices implicitly based on a standard level of linguistic and cultural understanding. Contextualized in specific social, cultural, and political dimensions, the Framework concepts require greater unpacking to reveal how international ELL students understand and apply them. By addressing Chinese international students' understanding of the Framework concept "authority is constructed and contextual," this exploratory study informs information literacy instructional practices when working with culturally embedded concepts, such as authority.

\section{Literature Review}

Librarians increasingly view themselves as educators of information literacy, ${ }^{5}$ an important skill for members of increasingly knowledge-based economies. ${ }^{6}$ Definitions of information literacy advocate for it as a human right ${ }^{7}$ and call for "deep information literacy," 8 which acknowledges that information literacy is culturally situated within a specific sociopolitical context. ${ }^{9}$ Elmborg criticizes the use of standards as universal models that may only be relevant for students whose "sociocultural identity merges seamlessly into this social system," ${ }^{10}$ arguing that "libraries can no longer be seen as value-neutral cultural space"11 and that their "grammars of information are reflections of a particular worldview - Anglo, Western, Christian, and predominantly male." 12 Hicks argues that viewing information literacy as a situated activity means that "information literacy standards cannot be characterized as neutral," as they "have emerged through culturally and ideologically specific conceptions of information competence."13

Trends away from standards have led to additional ways of characterizing information integral to a discipline, such as Meyer and Land's threshold concepts. ${ }^{14}$ Differing from core concepts of a discipline, threshold concepts transform understanding, acting as portals to new ways of thinking required for progression within a subject, idea, or worldview. To teach information literacy in a meaningful way, librarians have turned to threshold concepts to prioritize instructional content. ${ }^{15}$ With a basis in threshold concepts, the Framework identifies six concepts core to the understanding of information literacy: 1) authority is constructed and contextual; 2) information creation as a process; 3) information has value; 4) research as inquiry; 5) scholarship as conversation; and 6) searching as strategic exploration. However, not enough research has examined the Framework's cultural basis upon a particular worldview and how the emerging number of students coming from different sociocultural backgrounds understand its concepts.

Although growing, the library and information science (LIS) literature on international students remains limited in quantity and lacking in original research. ${ }^{16}$ A significant amount of this scholarship focuses on barriers to ELL library instruction. Of these, language is repeatedly cited as the greatest ${ }^{17}$ and has been identified as majorly impacting information literacy experiences. ${ }^{18}$ Shi argues that unequal cultural competence and limited linguistics of international students can disadvantage them in academic settings. ${ }^{19}$ Additional barriers noted in the literature include vocabulary and comprehension, ${ }^{20}$ plagiarism, reading, and understanding of academic materials. ${ }^{21}$ Furthermore, students may come to this educational environment with radically different preconceived notions of the library. ${ }^{22}$ 
Several studies have investigated the information-seeking behaviors of Chinese students. For example, Chen and Brown found that Chinese engineering graduate students preferred internet sources and electronic formats when conducting academic research. ${ }^{23} \mathrm{Liu}$ and Winn found that students lacked awareness of many library services and resources as well as a strong understanding of ethical information use, yet students did reflect confidence in their information searching. ${ }^{24}$ However, similar characteristics may exist for students from a number of backgrounds, including American students. In a study comparing native Chinese-speaking engineering students' information literacy challenges to those of their native English-speaking classmates, Zhao and Mawhinney found that both groups faced challenges in information literacy skills, such as locating full text when searching, synthesizing information, creating outlines, and writing persuasively. They did, however, identify unique challenges facing Chinese-speaking students, such as knowledge of basic library services and resources, as well as reading, writing, evaluating, and citing information. ${ }^{25}$

Fundamentally different cultural understandings between Eastern students and Western educational systems may also exist. Ross and Chen discuss the impact of Chinese international students' sociocultural values in three commonly referenced areas of silence in the classroom, self-segregation with other Chinese students, and instrumentalism. Yet, they emphasize that academic institutions' practices and policies often reinforce these behaviors and advocate for greater understanding and recognition of students' educational beliefs, experiences, and challenges across campus. ${ }^{26}$ Tang, Collier, and Will found that Chinese students perceived American institutions to be more rigorous, which simultaneously motivated them to study internationally while creating worry about succeeding academically. They also expected to encounter academic difficulties and identified significantly different classroom cultures as a hindrance to adjustment. ${ }^{27}$ The study from Martin et al. ${ }^{28}$ draws from Hofstede' $\mathrm{s}^{29}$ four dimensions of cultural differences affecting cross-cultural situations and identifies the most prevalent of these as individualism vs. collectivism and the degree of power distance, or the level of power inequality accepted within a society. In a study of international Chinese students' sense-making of information, Rodriguez found that students assessed authority of information based on an institution's reputation and rankings rather than content and quality, suggesting that assumptions regarding authority were informed by cultural understandings of information and organization of Chinese higher education. ${ }^{30}$ Such cultural differences may profoundly affect the way Chinese students grapple with Western understandings of authority and its construction within information literacy.

Therefore, when designing curriculum, librarians need to understand student experiences with information, ${ }^{31}$ as well as their cultural backgrounds. ${ }^{32}$ However, to genuinely meet the educational needs of ELLs, librarians need to examine factors such as social context, learner characteristics, learning conditions, learning process, and learning outcomes. ${ }^{33}$ Importantly, Hicks encourages librarians to step away from the "problem-deficit stance" focusing on barriers and disadvantages of international students that can lead to stereotypes surrounding their learning and cognition. ${ }^{34}$ In a survey investigating the experiences and needs of librarians serving international students, Ishimura and Bartlett found that librarians strongly recognized the importance of understanding students' cultural differences, yet in their own practice focused more on applying inclusive styles of communication and affective elements, demonstrating a need for greater access to information and training on working with cultural differences. ${ }^{35}$ 
While librarians recognize the importance of working with international students, not enough research addresses how ELLs actually understand and practice information literacy concepts introduced from a particular social and cultural worldview. This study seeks to fill this gap by investigating and describing how Chinese students understand and articulate concepts of authority within information literacy.

\section{Methodology}

This study used qualitative vignettes and in-depth interviews to explore how Chinese ELLs understand concepts of authority present within the Framework concept "authority is constructed and contextual." The vignette approach resulted in data coming from the voices of students themselves and allowed students to speak to their normative processes and behaviors without the influence of an expected answer or fear of "getting it wrong."

Vignettes are brief, hypothetical situations with fictional characters to which the interviewee responds. ${ }^{36}$ They provide a useful way to study perceptions, beliefs, attitudes, and opinions, as their relatable, situated context often absent in other qualitative approaches can generate more targeted responses and discussion from participants. ${ }^{37}$ Because participants respond to a fictional situation, vignettes work to personally distance the interviewee from the scenario while still gathering feedback about the issue under exploration - a particularly useful approach for obtaining information on normative behavior and cultural norms ${ }^{38}$ or sensitive, abstract, or difficult-to-define material. ${ }^{39}$ Although minimally applied in LIS research, Benedetti, Jackson, and Luo provide a recent detailed account exploring the vignette method and its potential in this field. ${ }^{40}$ They further detail this methodology as an avenue to explore more ambiguous threshold concepts found in the Framework for Information Literacy. ${ }^{41}$

For this study, the researchers, an academic librarian and an English for Speakers of Other Languages (ESOL) professor, developed four vignettes from the themes within the Framework concept "authority is constructed and contextual." Each vignette built around a specific objective: 1) to explore how students approach and react to new and varying perspectives, voices, or schools of thought; 2) to explore student perception of bias and opinion of the need to determine validity of information; 3) to explore the different types of authority defined by students; and 4) to understand what questions students ask when evaluating information. The vignette protocol was peer-reviewed by academic librarians and ESOL faculty. Three Chinese international students also piloted the protocol, providing feedback on the plausibility of the vignette scenarios, the comprehension of language and vocabulary used, and suggestions on vignette characters' names.

The study's population consisted of Chinese students in a pathway program at the University of Vermont. Inclusion criteria consisted of being at least 18 years old, attending high school in China, and studying in the United States for less than one year. Advertised through emails and announcements in second term pathway courses, the study used nonprobabilistic, purposive sampling of Chinese students. Eleven students decided to participate. This number aligns with the findings of Guest, who discovered that 6-12 in-depth interviews can achieve data saturation when working with a relatively homogenous sample and a consistent, structured instrument. ${ }^{42}$

The 11 in-depth interviews were analyzed using applied thematic analysis. ${ }^{43} \mathrm{~A}$ codebook was developed as outlined by MacQueen et al., ${ }^{44}$ consisting of data-driven codes, brief and full definitions of the codes, guidelines stating when to use or not use each code, and examples of the codes in the data. One researcher read the transcripts for themes and compiled an initial codebook. Both researchers then reviewed the codebook, individually coded 
several transcripts with it, and revised the codebook accordingly. After four iterations, a final codebook was established. To assess intercoder agreement, the researchers used subjective assessment ${ }^{45}$ in which the researchers independently coded each transcript, met to discuss and assess discrepancies in code, recoded the master documents based on consensus, and made any necessary refinements to code definitions. Following the protocol of this method, all discrepancies in coding were resolved during the process.

\section{Results}

\section{Vignette 1}

The first vignette (see box 1 below) explored students' reactions to new and varying perspectives. It centered on the following questions: 1 ) what do students think of perspectives they were previously unfamiliar with? and 2) how do they decide between sources with conflicting opinions?

\section{BOX 1}

\section{Vignette 1}

Jie has been studying nutrition for a class where he will be discussing the nutritional effects of eating meat. He has collected many sources that discuss why meat is such a beneficial protein for humans to eat. His own doctor has also told him that it's very important for his development to eat the proteins that come from meat. However, he just found several articles from a well-respected professor that disagree with this, saying that meat is not healthy and humans can get protein from a vegetarian diet. This idea is totally new and unfamiliar to him and goes against what he has previously learned about nutrition.

Follow-up questions:

1. If he wants to present the best information in his debate, how should Jie decide between these two different opinions?

2. How would you recommend that Jie approach this new perspective that he is unfamiliar with?

Participants revealed a strong hesitancy when asked how the vignette's character, Jie, should decide between conflicting nutritional advice from his family doctor and the articles of a well-known professor and resisted making initial judgments between the two sources. In fact, every participant maintained that Jie needed more information before making a decision. Advice on how Jie should gain this information varied across participants. Many suggested the need for additional research, such as searching online for more articles or specific data that could support or refute the ideas. Another common strategy consisted of asking the advice of an accessible, trusted third party, such as family members, friends, or professors.

Despite pushing for more information, several students revealed inclinations toward a particular source. For some, this depended on the type of information that each source could provide. For example, Participant 7 valued academic research and the reputation of the professor, noting: "Maybe I will support the second idea for the well-respected professor. Because, I think it has been published so it...must be, have planned many times... maybe the word 'well-respected' impressed me." However, others valued the doctor's experiential knowledge, arguing they needed to know more about the professor's research before trusting it: 
"Yeah, I believe the new idea, the article. I guess...it must be some research, but you know, human body is pretty complicated, and I believe the doctor, of course if he's a good doctor. He must be a good doctor. If he's not a good doctor, I will not trust him. So he has experience how some nutritional issue will act or react to, in people's bodies. So I will prefer to use more advice, opinions from doctors. Because he can consider from a practical, or I should say realistic, perspective. And the research is just research...so I will prefer to use some realistic data then just the research. Unless I can see in the research, there are many, some follow up study data. I prefer to trust this data." (Participant 3)

In some cases, participants' past knowledge and preferences influenced them more than the source's quality. Just fewer than half of the participants referred to their own beliefs about meat: one referencing his grandmother, who remains healthy on a vegetarian diet, and another showing remorse for those on a vegetarian diet, noting that they would miss out on "very tasty, tasty beef." Participant 9 argued that a person's own experience and opinion should be the guiding factor in making a decision:

“Well like I think it's important for your own opinion because it's nothing, uh maybe doctors say that the meat is...is good for you to eat, right. But I think maybe it's depend on yourself, and if you think maybe I can eat meat like 4 or 5 times a week, and then the rest of time I can eat vegetable, I think that's okay. It's not like, it's not you must be follow what doctor, the direction from doctor I think, yeah. Your opinion is more important."

All in all, despite revealing inclinations toward both sources of information, participants advocated for open-mindedness and the need for further research. They also relied strongly on their own experiences and beliefs surrounding dietary health, noting that they would continue to do so until they had enough evidence to convince them otherwise.

\section{Vignette 2}

The second vignette (see box 2) explored students' perception and recognition of bias and their opinion of the need to determine information's validity. It sought to address the following questions: 1) can students recognize potential bias in both traditional and nontraditional authorities? 2) are they skeptical of potential bias? and 3) do they think it's important to consider the source and its validity, regardless of reputation?

\section{BOX 2}

\section{Vignette 2}

As Jie continues his research, he decides to watch a debate about eating meat on YouTube. There are four experts participating in the debate. One of them is a nutritional scientist, one is the President and CEO of the American Meat Institute, one is a famous chef, and one is a famous author who writes about his experiences as a vegetarian. Two of them (the nutritional scientist and the vegetarian author) argue against eating meat. The other two (the chef and the $\mathrm{CEO}$ of the American Meat Institute) argue that eating meat has many benefits. 
Follow-up questions:

1. What advice would you give Jie before he listens to these four different people?

2. Are there any of these people that you would suggest he trust the most and, if so, why?

3. Should he trust their opinions and arguments for or against eating meat? Is there anything about their positions that you would caution Jie against believing?

When asked what advice Jie should have before listening to a debate on vegetarianism, the students suggested receptivity toward new information. Students advised that Jie be open-minded, neutral, and objective, using critical thinking when approaching the information. Other suggestions included doing initial research on the subject and looking up the backgrounds of the speakers.

Despite their initial appeal to open-mindedness, participants had strong preconceived opinions about the trustworthiness of the debaters based upon their positions and experiences, rather than their presented information. All but one participant recommended trusting the nutritional scientist the most, often arguing that her position alone accounted for this reliability. As Participant 4 stated, “...I believe the scientist. And personally, I'm believing science. And I don't believe some magic things or other things. That's only things we cannot explain with science now. So, I'm personally believing science." However, students also consistently identified qualities that inspired their trust in the scientist, such as prior research, education, and professionalism. Participant 1 noted, "... because if he is a scientist, maybe... he will prepare it for a long time and already do some research about it, so I think the resource may be more reasonable, and he already pay a lot of time to do it. So I think the more practice into something maybe the result will be more reliable."

Though participants upheld scientific experience as reliable and trustworthy, they did not similarly value all experiences. In fact, at times students viewed personal experience as a potential cause for bias. For example, they repeatedly accused the vegetarian author of bias due to his personal experience advocating for and loving vegetables. Similarly, several participants demonstrated wariness toward the chef, noting his job required him to make dishes taste good, not healthy, and therefore he would use meat if it benefited his career as a chef.

By far students directed the most distrust toward the CEO of the American Meat Institute, viewing this business affiliation as an automatic cause for concern due to the financial interest in meat consumption. Some students, such as Participant 2, felt that this business position alone could lead to dishonesty, noting "...the CEO of a meat institute, they're businessman. Sometimes businessmen will not tell the truth. And my parents also businessman. I know what they're talking about."

Students drew a strong connection between reliability and an implied lack of bias or personal benefit. Yet, despite such strong initial opinions based on the sources' positions and statuses, students ended this vignette by suggesting that Jie listen to all the sources but be cautious of them. Participant 3 concluded:

"It still depends on their opinions. And what materials they use to support their opinions. And keep, and keep in mind that we should pay attention...to the information's value and consider it is true or not, yeah. Compare with our own 
experience. I think the detail is the most important thing in debate, in any debate. We need some detail or some common knowledge that we know to support our ideas. If it's just a general idea, it's not specific enough for me."

\section{Vignette 3}

The third vignette (see box 3 ) explored the types of authority defined, used, and trusted by students. Specifically, it focused on the following questions: 1) do students recognize and acknowledge different types and levels of authorities? 2) when do they use or trust these different levels? and 3) does this authority change depending on different information needs or circumstances?

\section{BOX 3}

\section{Vignette 3}

Xiao Hong needs to research how the US president is elected. Before she tries to find information, she is going to make a list of the different groups of people who may know about the US voting and election system. After she makes this list, she can look for information from these groups to research her question. What groups of people should Xiao Hong include on her list?

Follow-up questions:

For the following situations, which source do you think she would use and why:

1. She wants to explain the situation to her friend at home in China who is interested in government. Which source(s) should she look to for information?

2. She needs to write a school paper on this system. Which source(s) should she look to for information to cite in the paper?

3. She wants to know who can vote in the next election. Which of these sources should she look to for information?

First, students listed different people or places to access when seeking information about the US election system. The most common of these, mentioned by 9 of 11 participants, included people with some version of expertise or professionalism, such as professors or political scientists. The second group included "ordinary" people, such as American citizens, friends, and classmates. Half of the students also identified government-based sources, such as politicians, government employees, or political websites, newspapers, or magazines. The last group included the internet, with examples such as Wikipedia or YouTube. When listing their potential sources, students often grouped them into hierarchical rankings, pointing out their respective values and differences.

In determining which sources to consult for different situations, participants consistently varied their answers based upon the information need at hand and provided justification for their choices. In the first situation, explaining the voting system to a curious friend in China, specific sources were consulted due to their accessibility, directness, convenience, and appropriate level of difficulty. Popular answers included Wikipedia, Facebook, or an American citizen who voted in the past. In choosing the Facebook page of a student government group, Participant 8 noted its suitability for the audience, "...I think maybe this one is like...more appropriate for student, is not that one should know really, like into the election system. Just want to know...what's the election system in the USA." Others, such as Participant 11, described the 
benefits of talking to a person with experience: "Maybe he has... an interesting experience... about the system. And maybe it's like a story when he talk about it. It's not like more, it's not like just the rules or the something in the website that's too academic...so it's like easier to understand it when he talk about it." However, one student warned against consulting US citizens, cautioning that they would not really know the system and reminded the researchers that the day after Brexit the most Googled phrase was "What is the EU? What is their job?"

In the second situation, participants were asked which of the sources to cite in a school paper. In this case, students frequently chose sources they defined as "reliable," "trustworthy," "official," and "believable." Specific sources included politicians, the author of a book on the United States government, and professors or "experts." Several students also suggested using Wikipedia, but not for the content on the page itself. Rather, students detailed strategies for using Wikipedia's background information to explain other sources or as a place to consult for further references on the subject. Participant 6 stated:

"I think she can go to the library to find some books. Because I think book is more reliable than the internet. So [s] he can find some information about the history... the American election, and get some very solid information about this election. And then [s] he can go to the teacher or ask her friend, some experience about the election, and I think...she will have some ideas."

The third information-seeking situation involved needing personal information about the requirements to vote in the United States. Participants identified this as an easy question, one that was "basic," rooted in facts, and "settled." Participant 4 explained:

“...because these things are not controversial. They're settled. Nobody can change it. And the quickest way to look up this settled information I think is Wikipedia. And, but people think Wikipedia page maybe not trustworthy because people, whoever you are can edit the page. Though the Encyclopedia [Britannica]. That would be good way to research."

Again, students often suggested American citizens as a source due to their personal experience with the information, accessibility, and convenience. Participant 5 detailed the benefits of this, noting "...ask the citizen of the American people. Yeah it's very easy and convenient. And he don't need to find out some information by himself. Just ask the question. I think that's very convenient." Participants also suggested more official sources, such as a voting office or government web pages. In several cases, participants suggested using multiple sources to validate the information coming from one source. Participant 3 noted, "if I was him, I will choose to, I will make research in each group and compare. Find the similarity. That must be true, I believe."

\section{Vignette 4}

The final vignette (see box 4) focused on uncovering what questions students ask when evaluating information. It sought to address which indicators of authority students look for and most value. 


\section{BOX 4}

\section{Vignette 4}

Jia has been asked by her professor to find a source on their class topic (renewable energy) this week. The professor said that it needs to be reliable (that the information should be accurate and factual) and that it should come from a credible source (that the person or organization producing the information can be trusted). So far she has found a few websites, a Facebook page of an environmental group, and some magazine and newspaper articles about the topic, but she doesn't know which of these sources to choose.

Follow-up questions:

1. What questions should Jia ask herself about the different sources to help her decide if they are credible and come from a reliable source?

2. Which of these do you think are the most important for her decision?

3. What makes it important?

In response to Jia deciding between sources for a class project, students applied several evaluation strategies. They demonstrated a keen awareness of the information need and made strong judgments between the appropriateness of different sources for a class assignment.

Throughout the interview, students often relied on their intuition in determining a source's reliability. For example, Participant 5 explained: "He can just look up the, each website ... to see the information, and just think...by himself to think is it reliable or useful." Participant 3 described a similar phenomenon: "So it's hard for me to explain how I feel when I find some resource. Just a kind of sense that I feel the source can be reliable because, maybe it is because I have read plenty of the articles in different field and maybe some books that are interesting. So I have this kind of, how to say that, intuitive? Intuition, yeah." Although they described it as intuition, students actually applied certain evaluative techniques, because when pressed, they described indicators they used to consider specific information use.

Every single participant listed examination of the information source (such as where it came from) as an evaluative strategy and described it as the most important indicator of authority. Participants suggested looking at the publication itself and noting its popularity, title, and size. They held well-known and "famous" publications, such as the New York Times, in high regard and suggested a relationship between a source's popularity and reliability. Participant 4 proposed using well-known publications, especially those also well known in China:

"I think that's trustworthy because like Time and The New Yorker, I think they are famous...you must have some reason to be famous. And like you have maybe two situation you can be famous. Like, you are good at it. Or you're good at to cater to people. And [either] of them can make you well respectful. Yes, I think choose the famous one is a good way."

Participant 9 described similar sentiments, suggesting looking at “...the magazine's name and newspaper's name. Maybe like New York Times magazine and Time magazine. These sort of thing. They must be, you can trust them. Yeah." However, students pushed back when asked if the information's reliability solely derived from its famous source. For example, Participant 6 explained that with fame came more responsibility, noting "because...they are famous, and 
they will have more responsibility to give the readers more reliable, the informations, and this is why many people will choose this publications to read the articles or get informations from this organizations." This same participant further explained that fame also leads to stronger vetting of better writers, resulting in higher-quality information.

Students revealed several additional evaluation strategies around source type, such as asking questions about its type (for instance: Is it academic?), creator, organization, amount and type of supporting evidence, and prioritizing web domains considered more trustworthy, such as .gov, .edu, or .org. Students also examined the purpose of the information. Participant 4 described this process in detail:

"So I think the first thing he needs to ask is 'is this information created to be academic?' So like, for example, the Facebook page of the environmental group, the purpose of they made this page is not for academic. They make for like people know what they are doing, or something like that. And I think the, how to say the word, the way to distinguish the academic and the normal one is a little bit... vague. And, like some examples, like if you found few websites like BBC... and newspaper or media, the well-respected, which means they be more trustworthy, and they will be care about the resources they use....But the Facebook page, people may not take the responsibility to say wrong things, so the purpose is just like entertaining."

Despite demonstrating awareness of basic evaluation strategies, students applied them inflexibly and sweepingly. For example, after suggesting looking for academic resources due to lack of bias, one of the interviewers asked if academic work ever contained bias. Participant 4 responded, "Yes. No bias...I think this is intolerant in academic one." Throughout their descriptions of the source types, students often voluntarily ranked sources in a hierarchy of trustworthiness and reliability, again revealing a strong judgment around what information should be used for academic work. Participant 3 explained: "You have your own thoughts. It is true or not? Is this valuable or not? Is it reliable or not? And I think, in my mind there is a priority of the information source.... So if I need to make an order, the first thing government website, the second is some famous magazine and newspaper site, the third one is common commercial site."

Another frequently mentioned method of evaluation was the validation of the information through an external source or third party. Suggestions included checking the sources listed in the information and looking at the number of the source's online views. Validation of the source also played a role in students' attachment to famous and well-known sources, because it entailed choosing a source that many other people read and agreed with. However, the most often listed strategy was to ask someone else about the source, primarily teachers or professors, followed by other classmates. Teachers were not only mentioned as a tool for validating information use, but also as the source that taught students how and when to apply the other evaluation strategies.

Finally, students also indicated a distrust of specific sources, primarily Facebook. This established itself as a general wariness toward opinions or informal information that could be created "anywhere" by "anyone." As Participant 11 clearly stated, "It's like by a person. A person can write Facebook, everyone can write a Facebook. So...it's like personal opinion about the thing...it's kind of like blog. So everyone can write about it...I don't want to trust them." 


\section{Discussion}

\section{Contextualized Information Literacy}

Throughout their interviews, participants frequently demonstrated a strong awareness of the specific information need's influence on the information type, access, and use. Importantly, students reflected that these components fluctuated depending on different contexts, realizing that varying situations require different levels and types of authoritative information. For instance, they pointed to more accessible and informal sources of information for personal, everyday information use but cautioned against these same sources for academic use. Yet despite being able to recognize critical elements necessary for considering information's use and authority in theory, students applied these elements much less critically in practice, evidenced by oversimplified ideas such as certain types of information never containing bias or some sources only having use at certain times and others having absolutely no use in certain situations. This reveals that these particular students have a baseline knowledge of the influence of the specific need and context when considering information's use, but they continue to require practice in applying these questions more critically and less generically.

In advocating for more description and less measurement of international students' information literacy, Hicks points out that "when we associate information literacy with the idea of what people do with information within a specific context, rather than as a checklist of competencies, research is re-focused on student actions and strategies within new settings." ${ }^{46}$ While this quote focuses on how to observe students' information literacy skills, it also has strong implications for teaching. Information literacy instruction should provide students with more opportunities for practicing and applying information literacy skills in differing settings to inform a more contextualized literacy. Not only will this better represent students' actual information literacy in practice, but it will help to problematize the rigid judgments students apply when determining resources' credibility and justifying their use or nonuse. Through more experience conceptualizing authoritative information in different situations, students can begin to build more nuanced and critical understandings of authoritative information.

\section{Information Evaluation}

Across the vignettes, students demonstrated awareness of the importance of evaluation and used different strategies to determine a source's credibility. Students frequently discussed the source of the information and the importance of using information they considered reliable, trustworthy, and accurate. Students asked evaluative questions of information sources, such as why the information was produced, what it was designed to do, and who created it. At times they used specific strategies, such as making hierarchical lists of potential sources or ranking several sources against each other. They also consistently discussed validating information they found through additional research or by consulting an expert.

One frequently mentioned method for seeking information or validating previously found information was to consult a trusted source, such as close family, friends, or teachers. Friends and family were much more often referred to in everyday information needs, a finding consistent with Sin's survey of international students' everyday life information seeking. ${ }^{47}$ In the present study, for more academic information needs, consultation of teachers and professors often replaced close friends and family. In fact, students revealed a very strong reliance on teachers throughout the interviews, at times even justifying a statement 
by noting "because my teacher told me so." Students may therefore benefit from greater explanation as to why their instructors suggest or require the use of certain resources. For example, rather than simply requiring students to meet checklists of source type and number, or to never cite specific resources, instructors should encourage reflection on the implications of varied information uses.

Students also relied heavily on their intuition or past experience when making judgments about what sources to consult. They described feelings of "just knowing" when a source should be used but had difficulty when asked to describe why. This may demonstrate that, while students can produce evaluative questions in the abstract, they have a harder time applying these questions in practice. Interestingly, students rarely mentioned evaluating the content of the information itself. Students may benefit from instruction challenging them to uncover their actual current evaluation strategies, especially when a source just "feels right." What are they considering when they make these decisions, and are they effective strategies? What did they include in their evaluation, and what did they leave out? More practice verbalizing these practices and procedures can help students gain confidence to uncover their current strategies, look at them critically, and continue to refine and improve them.

\section{Bias/Personal Experience}

While students quickly pointed out potential bias in information sources, they generally neglected to reflect on their own biases, judgments, and preconceived attitudes toward information. Students reflected polarized opinions about types of information. In some cases, they simply distrusted new information that did not align with their perspectives, but they also tended to make sweeping judgments about specific sources, such as personal experience being heavily biased, certain source types always being trustworthy, popularity equating reliability, and failing to question sources viewed as heavily authoritative, such as those coming from people with scientific or prestigious titles. All students, not just international students, come to higher education with preconceived understandings of information, and Angell and Tewell argue that librarians need to uncover and act upon these past understandings together with their students in information literacy instruction. ${ }^{48}$ In this way, instructors can help students to uncover their own biases and critically examine and build upon their own deeply rooted opinions.

\section{Limitations and Future Research}

As an exploratory, qualitative study, this research inquired into how a specific group of students articulated their understanding of authority within information. While the small sample size allowed the researchers' an in-depth view of specific students' understandings of information literacy components in their own words, it prevents broad transferability and generalization of findings. Furthermore, to reach data saturation, this study interviewed a fairly homogeneous group of students-Chinese students in a particular pathways program, with a specific range of linguistic aptitude and with a limited amount of time studying in the United States. As this study did not have a comparison group, it is unclear how much these findings relate to being a Chinese ELL student per se. In fact, many of the attitudes toward authority and evaluation strategies may not be substantially different from their American classmates. Therefore, future research is needed to expand similar questions to broader populations, both in quantity and demographics. 


\section{Conclusion}

This study examined Chinese ELL students' perceptions of authority in information as related to the ACRL Framework and encourages librarians to consider the implications of what they teach and how they teach it, realizing that not all concepts are universal to an increasingly diverse student body with a range of past experiences and cultural influences. The use of qualitative vignettes provided a concrete, culturally sensitive, and innovative way for Chinese ELL students to discuss their understanding of authority - a concept that could otherwise be difficult to describe or recognize in practice. It also helped to gather data about the shared, social knowledge of Chinese students studying abroad in the United States, rather than highly individualized experiences, while still enabling the student voice.

Though librarians recognize the necessity of understanding students' cultural differences, most research looks to the barriers international students face in library instruction and use. Rather than measuring the information literacy of these students, this study instead focuses on describing the strategies and experiences with information literacy that ELL students carry into the classroom and library. Study participants revealed multifaceted approaches to determining authority within information, including different evaluation and informationseeking strategies, as well as an attention to contextual influence. They also revealed areas for improvement and curricular focus, such as examination of personal biases and deeper critical thinking around information types. By focusing on students' actual practice of information literacy, librarians can build more informed, relevant, and accessible curriculum. Finally, this work encourages librarians and ESOL faculty to continue inquiring into students' application and understanding of concepts within their information literacy frameworks and paradigms.

\section{Notes}

1. "International Student Enrollment Trends, 1948/49-2017/18," Open Doors Report on International Educational Exchange (2018), https://www.iie.org/opendoors.

2. "International Student Totals by Place of Origin, 2012/13-2017/18," Open Doors Report on International Educational Exchange (2018), https://www.iie.org/opendoors.

3. University of Vermont, "Strategic Plan," Office of the President, University of Vermont (2013), https://www. uvm.edu/president/?Page=strategicplan.html.

4. Association of College \& Research Libraries (ACRL), Framework for Information Literacy for Higher Education (Chicago, IL: ACRL, 2015), last modified January 11, 2016, http://www.ala.org/acrl/standards/ilframework.

5. James Elmborg, "Critical Information Literacy: Implications for Instructional Practice," Journal of Academic Librarianship 32, no. 2 (March 2006): 192-99, https://doi.org/10.1016/j.acalib.2005.12.004.

6. Cara Bradley, "Information Literacy Policy Development in Canada: Is It Time?" Partnership: The Canadian Journal of Library and Information Practice and Research 8, no. 2 (2013), http://scholar.uwindsor.ca/lripub/9.

7. Paul Sturges and Almuth Gastinger, "Information Literacy as a Human Right," Libri 60, no. 3 (January 2010), https://doi.org/10.1515/libr.2010.017.

8. Laurie Kutner and Alison Armstrong, "Rethinking Information Literacy in a Globalized World," Communications in Information Literacy 6, no. 1 (2012): 24-33.

9. Heidi L.M. Jacobs, "Information Literacy and Reflective Pedagogical Praxis," Journal of Academic Librarianship 34, no. 3 (May 2008): 256-62, https://doi.org/10.1016/j.acalib.2008.03.009; Rolf Norgaard, "Writing Information Literacy: Contributions to a Concept," Reference \& User Services Quarterly 43, no. 2 (Winter 2003): 124-30.

10. Elmborg, "Critical Information Literacy," 194.

11. Elmborg, "Critical Information Literacy," 198.

12. Elmborg, "Critical Information Literacy," 197.

13. Alison Hicks, "Reframing Librarians' Approaches to International Student Information Literacy through the Lens of New Literacy Studies," in Critical Literacy for Information Professionals, ed. Sarah McNicol (London, UK: Facet Publishing, 2016), 43-56.

14. Jan H.F. Meyer and Ray Land, “Threshold Concepts and Troublesome Knowledge: Linkages to Ways of 
Thinking and Practising within the Disciplines," in Improving Student Learning Theory and Practice: Ten Years On, ed. Chris Rust (Oxford, UK: OCSLD, 2003).

15. Lori Townsend, Korey Brunetti, and Amy R. Hofer, "Threshold Concepts and Information Literacy," portal: Libraries and the Academy 11, no. 3 (July 2011): 853-69.

16. Amanda B. Click, Claire Walker Wiley, and Meggan Houlihan, "The Internationalization of the Academic Library: A Systematic Review of 25 Years of Literature on International Students," College E Research Libraries 78, no. 3 (March 2017): 328-58, https://doi.org/10.5860/crl.78.3.328

17. Dawn Amsberry, "Talking the Talk: Library Classroom Communication and International Students," Journal of Academic Librarianship 34, no. 4 (July 2008): 354-57, https://doi.org/10.1016/j.acalib.2008.05.007; Miriam Conteh-Morgan, "Connecting the Dots: Limited English Proficiency, Second Language Learning Theories, and Information Literacy Instruction," Journal of Academic Librarianship 28, no. 4 (July 2002): 191-96, https://doi. org/10.1016/S0099-1333(02)00282-3.

18. Nicole Johnston, Helen Partridge, and Hilary Hughes, "Understanding the Information Literacy Experiences of EFL (English as a Foreign Language) Students," Reference Services Review 42, no. 4 (November 10, 2014): 552-68, https://doi.org/10.1108/RSR-05-2014-0015.

19. Xingsong Shi, "Negotiating Power and Access to Second Language Resources: A Study on Short-Term Chinese MBA Students in America," Modern Language Journal 95, no. 4 (2011): 575-88.this study contends that being situated in the second language (L2

20. Johnston, Partridge, and Hughes, "Understanding the Information Literacy Experiences of EFL (English as a Foreign Language) Students."

21. Julia A. Martin et al., "Relationship Building with Students and Instructors of ESL: Bridging the Gap for Library Instruction and Services," Reference Services Review 40, no. 3 (August 10, 2012): 352-67, https://doi. org/10.1108/00907321211254634.

22. Martin et al., "Relationship Building with Students and Instructors of ESL”; Christina Pracha, Mary Stout, and Lisa Jurkowitz, "Information Literacy Program Development for ESL Classes in a Community College," Community \& Junior College Libraries 13, no. 4 (May 31, 2005): 17-39, https://doi.org/10.1300/J107v13n04_06.

23. Yao Chen and Cecelia Brown, "Ensuring Chinese Engineering Graduate Students' Academic Success: A Study at the University of Oklahoma," Science $\mathcal{E}$ Technology Libraries 31, no. 3 (2012): 320-41, https://doi.org/10.1 080/0194262X.2012.705144

24. Guoying Liu and Danielle Winn, "Chinese Graduate Students and the Canadian Academic Library: A User Study at the University of Windsor," Journal of Academic Librarianship 35, no. 6 (November 2009): 565-73, https://doi-org.cobalt.champlain.edu/10.1016/j.acalib.2009.08.001.

25. Jennifer Congyan Zhao and Tara Mawhinney, "Comparison of Native Chinese-Speaking and Native English-Speaking Engineering Students' Information Literacy Challenges," Journal of Academic Librarianship 41, no. 6 (November 2015): 712-24, https://doi.org/10.1016/j.acalib.2015.09.010.

26. Heidi Ross and Yajing Chen, "Engaging Chinese International Undergraduate Students in the American University," Learning and Teaching 8, no. 3 (January 1, 2015), https://doi.org/10.3167/latiss.2015.080302.

27. Xiaokang Tang, Daniel A. Collier, and Allison Witt, "Qualitative Study on Chinese Students' Perception of U.S. University Life," Journal of International Students 8, no. 1 (Jan./Feb. 2018): 151-74, https://doi.org/10.5281/ zenodo.1134279

28. Martin et al., "Relationship Building with Students and Instructors of ESL."

29. Geert Hofstede, "Cultural Differences in Teaching and Learning," International Journal of Intercultural Relations 10 (1986): 301-20.

30. Elisabeth Rodriguez, "Information-Seeking Behavior and the Intercultural Learning Process: Experiences of International Graduate Students from China: A Qualitative Sense-Making Case Study," University of Pittsburgh ETD (June 17, 2014), http://d-scholarship.pitt.edu/21713/.

31. Johnston, Partridge, and Hughes, "Understanding the Information Literacy Experiences of EFL (English as a Foreign Language) Students."

32. Martin et al., "Relationship Building with Students and Instructors of ESL."

33. Conteh-Morgan, "Connecting the Dots."

34. Hicks, "Reframing Librarians' Approaches to International Student Information Literacy through the Lens of New Literacy Studies."

35. Yusuke Ishimura and Joan C. Bartlett, "Are Librarians Equipped to Teach International Students? A Survey of Current Practices and Recommendations for Training," Journal of Academic Librarianship 40, no. 3/4 (May 2014): 313-21, https://doi.org/10.1016/j.acalib.2014.04.009.

36. Janet Finch, "The Vignette Technique in Survey Research," Sociology 21, no. 1 (1987): 105-14.

37. Paul Fleming and Michael Stalker, "Using Vignettes in Public Health Research," in Public Health Research 
Methods, eds. Greg Guest and Emily Namey (Thousand Oaks, CA: Sage, 2015).

38. Finch, "The Vignette Technique in Survey Research."

39. R. Halper et al., “\#DitchTheSurvey: Expanding Methodological Diversity in LIS Research," In the Library with the Lead Pipe (March 11, 2015), www.inthelibrarywiththeleadpipe.org/2015/ditchthesurvey-expandingmethodological-diversity-in-lis-research/.

40. Allison Benedetti, John Jackson, and Lili Luo, “Vignettes: Implications for LIS Research," College E Research Libraries 79, no. 2 (2017): 222-36, https://doi.org/10.5860/crl.79.2.222.

41. Benedetti, Jackson, and Luo, "Vignettes: Implications for LIS Research," 226.

42. Greg Guest, Arwen Bruce, and Laura Johnson, "How Many Interviews Are Enough? An Experiment with Data Saturation and Variability," Field Methods 18, no. 1 (February 1, 2006): 59-82, https://doi. org/10.1177/1525822X05279903.

43. Greg Guest, Kathleen M. MacQueen, and Emily E. Namey, Applied Thematic Analysis (Los Angeles, CA: Sage Publications, 2012).

44. Kathleen M. MacQueen et al., "Team-based Codebook Development: Structure, Process, and Agreement," in Handbook for Team-Based Qualitative Research, eds. Greg Guest and Kathleen M. MacQueen (Lanham, MD: Altamira Press), 119-35.

45. Guest, MacQueen, and Namey, Applied Thematic Analysis, 89.

46. Hicks, "Reframing Librarian Approaches to International Student Information Literacy through the Lens of New Literacy Studies," 50.

47. Sei-Ching Joanna Sin, "Demographic Differences in International Students' Information Source Uses and Everyday Information Seeking Challenges," Journal of Academic Librarianship 41, no. 4 (July 2015): 466-74, https://doi.org/10.1016/j.acalib.2015.04.003."plainCitation":"Sei-Ching Joanna Sin, “Demographic Differences in International Students' Information Source Uses and Everyday Information Seeking Challenges," The Journal of Academic Librarianship 41, no. 4 (July 2015

48. Katelyn Angell and Eamon Tewell, "Teaching and Un-Teaching Source Evaluation: Questioning Authority in Information Literacy Instruction," Communications in Information Literacy 11, no. 1 (2017): 95-121, https://doi. org/10.15760/comminfolit.2017.11.1.37. 